\title{
Aquatic Organic Matter in the Seine Basin: Sources, Spatio-Temporal Variability, Impact of Urban Discharges and Influence on Micro-pollutant Speciation
}

\author{
G. Varrault, E. Parlanti, Z. Matar, J. Garnier, P. T. Nguyen, S. Derenne, \\ V. Rocher, B. Muresan, Y. Louis, C. Soares-Pereira, A. Goffin, \\ M. F. Benedetti, A. Bressy, A. Gelabert, Y. Guo, and M.-A. Cordier
}

\section{Contents}

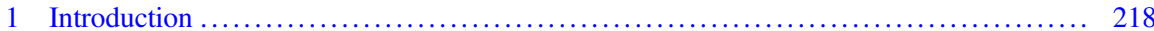

2 Sources and Variability of Organic Matter in the Seine River Watershed ............. 220

2.1 Context and Objectives .......................................... 220

2.2 Methods for Characterising Organic Matter in River Water ................. 220

2.3 Sources and Spatio-Temporal Variability of OM in the Seine River Basin ........ 223

2.4 Impact of the Paris Conurbation Discharges on DOM Quantity and Quality

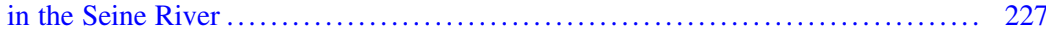

3 Influence of Organic Matter on the Fate of Micro-pollutants and the Role Played by Urban

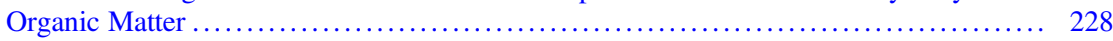

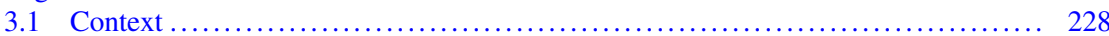

3.2 Material and Methods ................................................. 229

3.3 Characterisation of DOM Trace Metal-Binding Ability .................... 230

The copyright year of the original version of this chapter was corrected from 2019 to 2020 . A correction to this chapter can be found at https://doi.org/10.1007/698_2020_667

G. Varrault (四), Z. Matar, B. Muresan, Y. Louis, C. Soares-Pereira, A. Goffin, and A. Bressy LEESU, Université Paris-Est Créteil, École des Ponts ParisTech, Université Paris-Est, Créteil, France e-mail: varrault@u-pec.fr

E. Parlanti, P. T. Nguyen, Y. Guo, and M.-A. Cordier

Univ. Bordeaux, CNRS, UMR 5805 EPOC, Talence, France

J. Garnier and S. Derenne

SU CNRS EPHE UMR 7619 METIS, Paris, France

V. Rocher

SIAAP, Direction Innovation, Colombes, France

M. F. Benedetti and A. Gelabert

Equipe Géochimie des Eaux, Univ. Paris Diderot, Sorbonne Paris Cité, Institut de Physique du Globe - UMR 7154, Paris, France 
3.4 Contribution of EfDOM from Seine-Aval WWTP to the Copper-Binding Site Flux in the Seine River Downstream of Paris ................................ 232

3.5 Modelling of Trace Metal Speciation in the Seine River Upstream and Downstream of the Paris Conurbation .............................................. 233

3.6 Evaluation of the Role of DOM on Copper Bioavailability Toxicity to Daphnia magna ............................................................ 235

3.7 Effect of EfDOM on Trace Metal Sorption by Mineral Particles in Aquatic Systems Subjected to Strong Urban Pressure .................................... 236

3.8 Effect of EfDOM on PAH Adsorption by Mineral Particles in Aquatic Systems

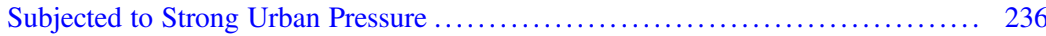

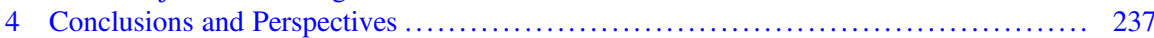

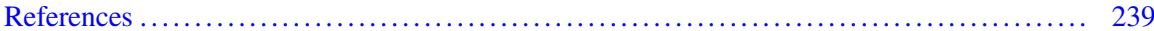

\begin{abstract}
This research has been conducted over the last 10 years to characterise the spatio-temporal variability of aquatic organic matter (OM) composition in the Seine River watershed upstream and downstream of Paris Megacity and its effect on micro-pollutants. For this purpose, a large number of samples were collected under different hydrological conditions, and, over 1 year, three representative sites were monitored monthly. Furthermore, the evolution of the OM composition along an urbanisation gradient, from upstream to downstream of the Paris agglomeration, was characterised, highlighting the very strong impact of urban discharges, especially during low-water periods. Substantial differences in the chemical composition are emphasised relative to the urban or natural origin of the organic matter. Dissolved organic matter (DOM) interactions with metallic and organic micropollutants were studied, allowing us to (1) identify the key role of DOM on their speciation and bioavailability in aquatic systems and (2) demonstrate that these interactions depend on DOM composition and origin. The essential role of urban DOM on the speciation of trace metals in the Seine River downstream of the Paris agglomeration is also shown.
\end{abstract}

Keywords Adsorption, Complexation, Dissolved organic matter, EEM fluorescence spectroscopy, eLTER, Monitoring campaigns, PAHs, Particulate organic matter, PIREN-Seine, Snapshot campaigns, Trace metals, Water, Zone Atelier Seine

\title{
1 Introduction
}

In freshwater environments, organic matter (OM), including particulate (POM) and dissolved (DOM) forms, is a highly complex and dynamic mixture of organic compounds derived from both natural sources and anthropogenic inputs [1-3]. The allochthonous (terrestrial plant detritus and soils) or autochthonous (in situ aquatic production) origin of natural organic matter (NOM) determines its composition and properties driving microbial processing, carbon cycling and its reactivity in aquatic ecosystems [4, 5]. NOM is mainly formed by biogeochemical processes such as photosynthesis, excretion or secretion by organisms, biomass decay or diagenesis [1]. The concentration and composition of both DOM, including colloidal OM, and 
POM depend on the surrounding watershed and on the hydrological connectivity between the main channel, backwaters and groundwater, which control the transfer of terrestrial and aquatic-derived OM in freshwater ecosystems [4]. Despite the conventional agreement that terrestrial organic carbon is recalcitrant and transported conservatively along streams and rivers with little contribution to aquatic metabolism, recent studies indicate that it is much less refractory and has a greater bioavailability than previously thought $[4,6,7]$.

OM plays an essential role in shaping aquatic ecosystems [8] because of the number of processes in which it becomes involved. Whatever its sources, it has a pivotal role in the autotrophy/heterotrophy balance in river systems, as described in detail in Garnier et al. [9]. OM is also well known to influence the speciation, solubility, toxicity and transport of organic and inorganic pollutants [10, 11]. Furthermore, DOM is also involved in aqueous photochemical reactions, nutrient cycling and availability $[12,13]$. The mechanisms involved in all these processes are strongly dependent not only on the overall concentration of OM but also on its chemical nature, physicochemical properties and composition in the aquatic environment. Moreover, human activities alter fluvial NOM properties with OM inputs from agricultural and forest practices as well as urban, domestic and industrial sewage [1,2]. OM is also a major concern in wastewater and drinking water treatments [14-16], affecting the efficiency of water treatment processes, the colour, odour and taste in water and resulting in the formation of disinfection by-products [15-17].

Despite their key role in environmental processes, OM composition and reactivity are still poorly understood. The characterisation of $\mathrm{OM}$ and its influence on the speciation of pollutants have been investigated, since 2010, in the Seine River system, as described in this chapter, and contribute to new insights into the role of $\mathrm{OM}$ in freshwater ecosystem functioning, its spatial and seasonal variability and its interaction with contaminants. This chapter focuses most particularly on the distinction between different $\mathrm{OM}$ sources, including urban point sources, interactions with watershed soils and in-stream processes.

The discharge of wastewater (treated or not) is a significant source of organic matter for the Seine River. A major trend in the trajectory of the Seine River system over the past 50 years has been the gradual improvement of wastewater treatment and the reduction in the loading of point sources of contamination to the river. The long-term trends in water quality and especially the changes in organic pollution from urban point sources are fully described in the Chapter 8 . Globally, the quality of wastewater treatment has been very strongly and gradually improved since the 1970s [18]. Between 1970 and 1980, the flow of biochemical oxygen demand $\left(\mathrm{BOD}_{5}\right)$ discharged into the river decreased from 70,000 tonnes year ${ }^{-1}$ to 45,000 tonnes year ${ }^{-1}$. This flow remains constant until 1995 and then decreases sharply to reach 20,000 tonnes year ${ }^{-1}$ in 2005 and 10,000 tonnes year ${ }^{-1}$ in 2015. The decrease occurred later for Kjeldahl nitrogen, i.e. from 30,000 tonnes year ${ }^{-1}$ between 1987 and 2007 to less than 10,000 tonnes year ${ }^{-1}$ since 2007, following the commissioning of the nitrification unit at the Seine-Aval wastewater treatment plant (WWTP) [18]. Despite the very significant improvement in wastewater treatment and thus in water quality in the Seine River over the past 50 years, questions still remain on the role of $\mathrm{OM}$ in the transport of nutrients and contaminants from land to sea and on the 
impact of OM characteristics on the ecological status and ecosystem services of the river. Since the analytical methods for characterising $\mathrm{OM}$ and its interaction with contaminants were not available in the 1970s, when wastewater contamination was much higher, it is thus not possible to identify any trend regarding how the influence of the type of $\mathrm{OM}$ on water quality and river system functions has evolved in comparison to the situation in the 1970s. The studies described in this chapter nevertheless present the current state of the system and will allow to study in the future potential changes in $\mathrm{OM}$ characteristics and reactivity.

\section{Sources and Variability of Organic Matter in the Seine River Watershed}

\subsection{Context and Objectives}

$\mathrm{OM}$ in aquatic systems plays an important role in water quality and biogeochemical processes [1]. The biogeochemical functioning of the Seine River basin has been largely studied over the last few decades within the PIREN-Seine multidisciplinary scientific programme [19]. The water quality and ecological functioning of the Seine River watershed have been mainly investigated through material budget approaches applied to biogenic elements $[20,21]$ as well as to chemical and microbiological contaminants [22, 23]. Previous investigations concerning carbon in the Seine River basin mainly focused on organic carbon fluxes [24], biogeochemical mass balances (C, N, P, Si) [20], methane emissions [25] or production and respiration [21]. However, not only dissolved organic carbon (DOC) quantity but also its quality reflect the dynamic interaction between OM sources and biogeochemical processes [26] and are likely to have ecological repercussions [27, 28].

To achieve a better understanding of OM environmental role in aquatic ecosystems, it is essential to improve the knowledge on its physicochemical properties and composition in the aquatic environment. The main goals of the studies conducted since 2010 on the biogeochemistry of the Seine River within the PIREN-Seine programme were to characterise the sources and properties of OM and their spatiotemporal variability in the Seine River watershed.

\subsection{Methods for Characterising Organic Matter in River Water}

To assess the variability of $\mathrm{OM}$ characteristics from both quantitative and qualitative points of view, surface water samples were collected in 23 and 39 sites at low water (November 2011 and September 2012) and 40 sites at flood levels (Fevrier 2013), from the Seine River, the Oise River, the Marne River and its main tributary the 
Grand Morin River upstream of the Paris urban area and in the Seine River downstream of Paris urban area and downstream of the largest discharge point of wastewater occurring through the effluents of the Seine-Aval WWTP at Achères (Fig. 1).

Monthly monitoring was carried out over a 1-year period upstream and downstream of the Paris agglomeration in order to highlight the impact of the urban discharges on the DOM of the Seine River in terms of both quality and quantity [29]. There were nine sampling campaigns from October 2010 to September 2011, and three sites were sampled:

- Ussy-sur-Marne (labelled "Upstream I"; open blue circle on Marne River in Fig. 1) and Fontaine-le-Port (labelled "Upstream II"; open blue circle on Seine River upstream Paris in Fig. 1) are located upstream of the conurbation on the Marne and Seine Rivers, respectively. Due to the low population density in their catchment, these two sites were chosen as reference sites given that they were exposed to a low impact from urban discharges.

- Andresy (labelled "Downstream"; open blue circle on Seine River downstream Paris in Fig. 1) is located downstream of Paris approximately $9 \mathrm{~km}$ from the Seine-Aval WWTP outlet, ensuring a good level of mixing in Seine River water. This site was selected as being under high urban pressure.

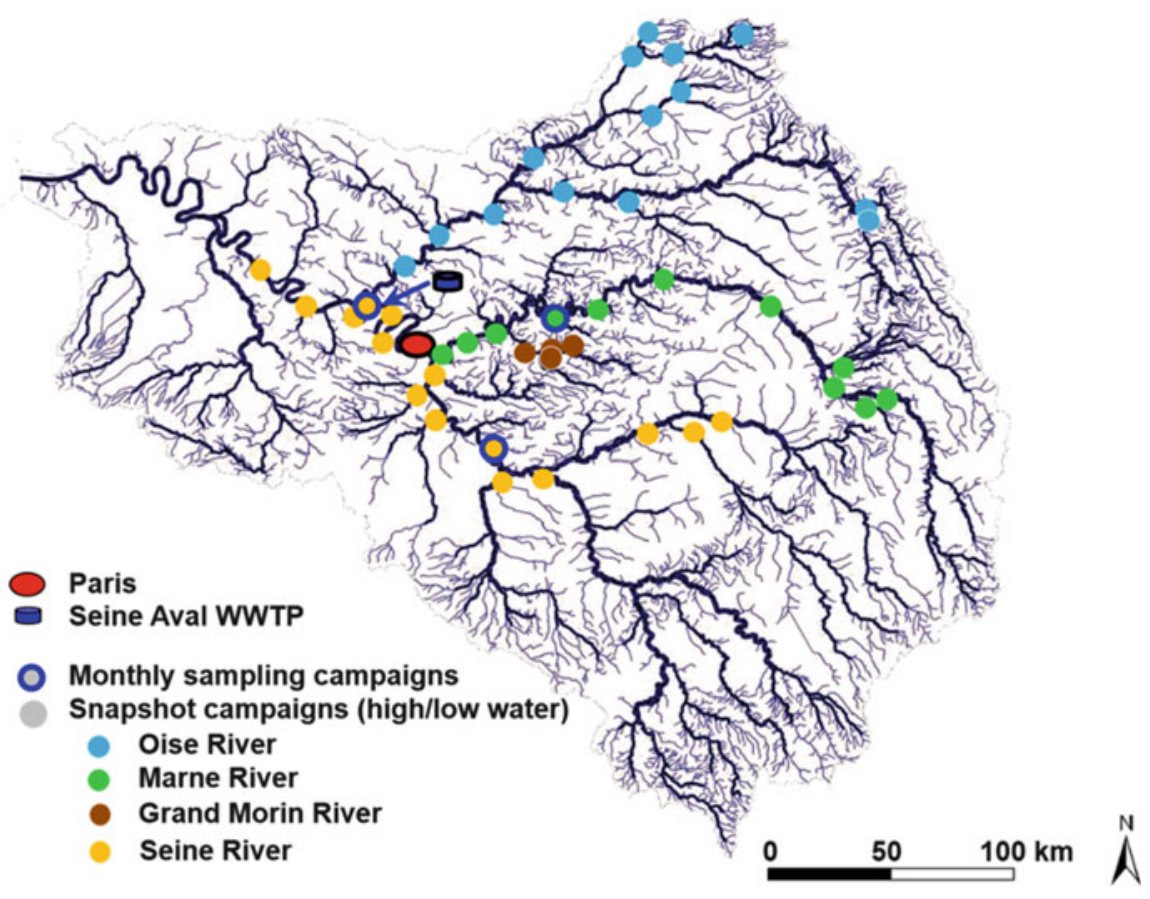

Fig. 1 Location of the different sampling sites in the Seine River and its main tributaries: the Oise River, the Marne River and the Grand Morin River. Filled circles, snapshot campaigns; open blue circles, monthly campaigns upstream and downstream from the Paris conurbation 
In addition, more sampling campaigns were carried out in low-water periods (eight campaigns between 2011 and 2014) and flood in February 2013 to determine longitudinal profiles of particulate organic matter (POC), DOC and biodegradable DOC (BDOC) concentrations.

The mean discharge observed at the Paris gauging station (Austerlitz) was around $100 \mathrm{~m}^{3} \mathrm{~s}^{-1}$ for both low-water campaigns. The contribution of the large reservoirs in the upstream basin regulating the hydrology of the Seine River was about 50\% in August/September 2012 compared to only 20\% in November 2011. The highwater campaign occurred in February 2013 with flows amounting to $700 \mathrm{~m}^{3} \mathrm{~s}^{-1}$ for the Seine River at Alfortville - the confluence of the Seine and Marne Rivers - with a contribution of $350 \mathrm{~m}^{3} \mathrm{~s}^{-1}$ by the Marne River at Gournay, and $280 \mathrm{~m}^{3} \mathrm{~s}^{-1}$ at Creil for the Oise River, a downstream tributary of the Seine.

DOM, including colloidal organic matter, and POM were separated immediately after sampling by filtration on precombusted $\left(450^{\circ} \mathrm{C}\right.$ ) glass fibre filter (Whatman GF/F $0.70 \mu \mathrm{m}$ ). As shown in Fig. 2, both DOM and POM fractions could then be characterised in terms of biodegradability, hydrophobicity and other chemical properties owing to a wide range of analytical methods.

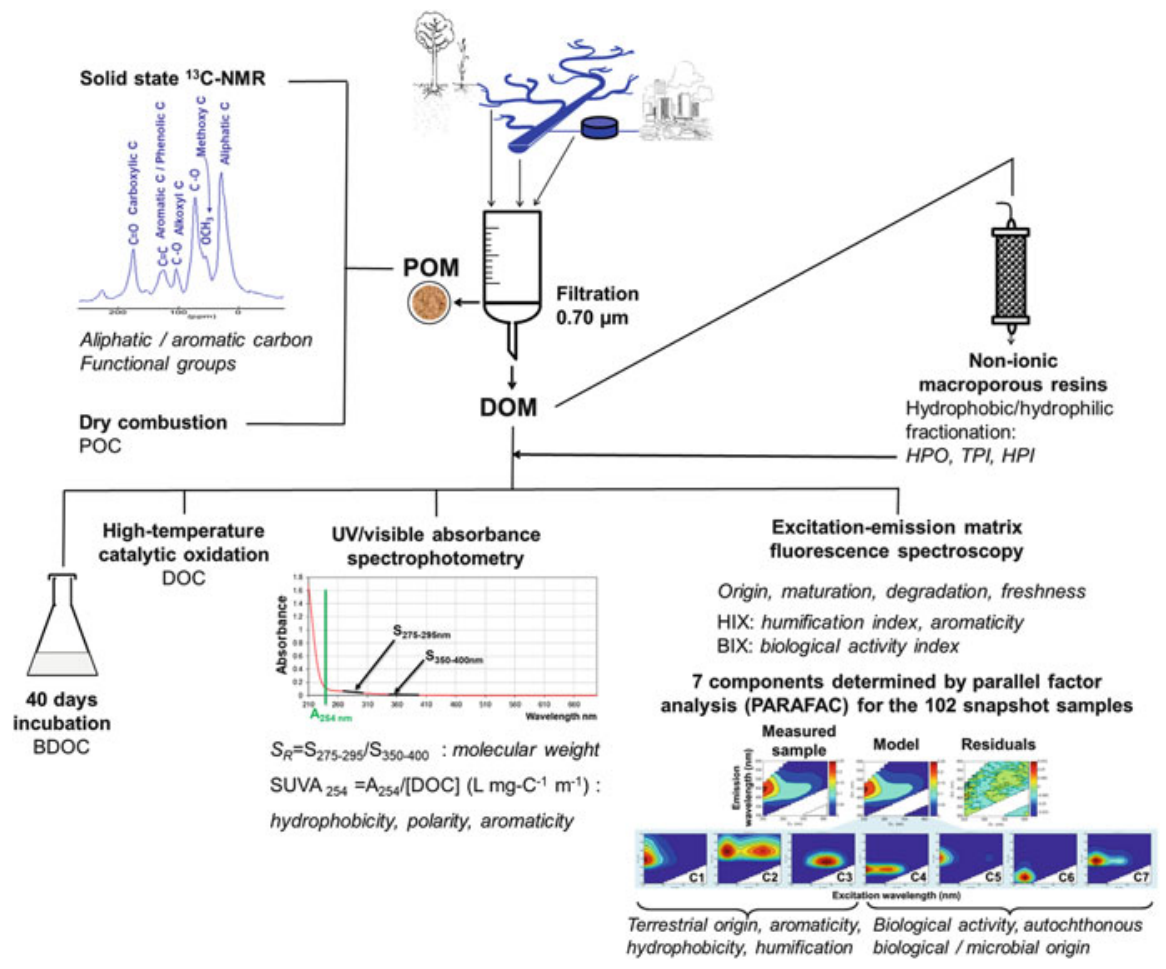

Fig. 2 Different analytical techniques used for the separation or the characterisation of particulate (POM) and dissolved (DOM) organic matter 
The organic carbon content was determined by POC and DOC hightemperature combustion measurements, and BDOC was assessed through incubation experiments [30].

Nuclear magnetic resonance (NMR) spectroscopy has been largely used to investigate NOM structure [31]. To identify the main functional groups of OM in the Seine River catchment, the solid-state ${ }^{13} \mathrm{C}$ NMR spectra were recorded for POM isolated on glass fibre filters after filtration of 3-10 L of surface waters collected from selected sampling sites during the low water (2012) and flooding (2013) campaigns.

For selected sampling sites, about $10 \mathrm{~L}$ of surface waters collected in low water (2012) and flooding (2013) periods were fractionated on non-ionic macroporous DAX-8 and XAD-4 resins so as to separate DOM into different fractions according to polarity criteria. The hydrophobic (HPO), transphilic (TPI) and hydrophilic (HPI) fractions were thus isolated according to a protocol described elsewhere [29].

The application of optical properties as a proxy for DOM composition and reactivity in aquatic environments has been extensively applied [28]. To gain information on its origin, dynamics and degree of transformation, UV/visible absorbance and excitation emission matrix (EEM) fluorescence spectroscopy combined with parallel factor analysis (PARAFAC) were used to characterise DOM in the Seine River watershed [32]. UV/visible absorbance spectroscopy was used to determine DOM properties at natural $\mathrm{pH}$. The spectral slope ratio $S_{R}\left(S_{R}=\mathrm{S}_{275-295 \mathrm{~nm}} / \mathrm{S}_{350-400 \mathrm{~nm}}\right)$ was used to estimate the variation of the molecular weight of DOM; the molecular weight decreases when $S_{R}$ increases [33]. The specific UV absorbance at $254 \mathrm{~nm}\left(\mathrm{SUVA}_{254}\right)$ is strongly correlated with the hydrophobic organic acid fraction of DOM and is a useful proxy for DOM aromatic content and molecular weight [34]. Information on the origin and the transformation degree of DOM can be obtained through the calculation of the humification index (HIX) [35] and the biological index (BIX) [36].

\subsection{Sources and Spatio-Temporal Variability of OM in the Seine River Basin}

For the three snapshot campaigns, DOC concentrations were not significantly different among the Seine, Marne and Oise subbasins, whether it was in low or high waters (about $3 \mathrm{mgC} \mathrm{L}^{-1}$ ), with, however, slightly higher values observed for the Oise subbasin. For the Seine River, DOC concentrations were higher downstream of Paris, and this increase of DOC amounts between the upstream and downstream of the Paris conurbation was more pronounced at low water. The biodegradable fraction (BDOC), however, differed by a factor $>4(28 \%$ vs. $6 \%$ in low water vs. high water, respectively). The Oise River was clearly distinguished by its higher POC content in suspended solids during the high flow in February 2013, much higher than the values of the other subbasins. 
The HPO, TPI and HPI fractions were isolated, according to DOM polarity, from 14 surface water samples collected in the low-water period in 2012 and 17 during flooding in 2013. At low-water period, the proportion of DOC in the different fractions showed little variation between sampling sites with the HPO, TPI and HPI fractions averaging $31 \%, 27 \%$ and $42 \%$ of DOC, respectively. The HPI proportion was slightly higher in the subbasins of the Marne River and the Seine River, however. These results point out the higher presence of fresh autochthonous DOM at this low-water period. During flooding, the distribution of DOC was also homogenous between the three fractions, with $43 \%, 29 \%$ and $28 \%$ for the HPO, TPI and HPI fractions, respectively. A strong increase of the hydrophobic fraction $(+40 \%)$ and a decrease of the hydrophilic fraction highlighted greater terrestrial inputs for this hydrological condition.

The structural characterisation of POM was investigated by ${ }^{13} \mathrm{C}$ NMR analysis of a few selected samples, representative of the whole Seine River watershed. The analysis of the ${ }^{13} \mathrm{C}$ NMR spectra demonstrated great spatial variability of POM characteristics. Samples from the Oise River and the upstream Seine River collected in 2012, during a low-water period, were characterised by fresh OM, mainly polysaccharides, with also a high terrestrial contribution revealed by the presence of lignin. Spectra of samples collected in the upstream Oise River and in the Seine River downstream of Paris at the same period showed a decrease of aliphatic carbon and carbohydrate signals with a relative increase of the aromatic carbon signal, highlighting the presence of more humified organic material. Except for one location in the upstream Oise River, differences were observed between spectra recorded for all sampling sites in low-water and flood conditions. During flooding, POM for samples in the Oise River and the upstream Seine River exhibited more aromatic characteristics, while fresh material was observed in the upstream Oise River, in contrast to results for the low-water stage. For the two samples in the Oise River and the upstream Seine River, the lower freshness character of OM observed with a higher DOC content could suggest an input of OM from groundwater. Conversely, soil surface leaching could explain the presence of more recent OM and higher DOC levels for the upstream Oise River sample. A high spatial and temporal variability of POM characteristics depending on hydrological connectivity and conditions was thus highlighted by ${ }^{13} \mathrm{C}$ NMR analysis.

The optical properties of DOM were determined, after filtration, for all surface water samples collected during the three snapshot campaigns.

The highest values of $S_{R}$ were observed for samples collected from the Marne River in low-water periods (2011 and 2012), reflecting the presence of lower molecular weight $\mathrm{OM}$ in this area, whereas we noted, for all the sampling sites in 2013 (flooding), the lowest $S_{R}$ values, corresponding to higher-molecular-weight OM. Three of the four samples collected from the Grand Morin River in 2011 were also characterised by organic components of high molecular weight (HMW; low $S_{R}$ values) as in the 2013 flood. As for the samples of the Seine River in 2012, they were characterised by low-molecular-weight (LMW) DOM and especially upstream of Paris [32].

It is considered that natural waters with high SUVA $_{254}$ values $\left(\geq 4 \mathrm{~L} \mathrm{mg}^{-1} \mathrm{C} \mathrm{m}^{-1}\right)$ have relatively high contents of hydrophobic, aromatic and high-molecular- 
weight DOM, whereas waters with $\mathrm{SUVA}_{254}$ values $\leq 2-3 \mathrm{~L} \mathrm{mg}^{-1} \mathrm{C} \mathrm{m}^{-1}$ contain a mixture of hydrophobic and hydrophilic DOM from various sources with a range of molecular weights. The highest $\mathrm{SUVA}_{254}$ value was determined for one sample from the Oise River in $2011\left(5.3 \mathrm{~L} \mathrm{mg}^{-1} \mathrm{C} \mathrm{m}^{-1}\right)$, reflecting a relatively high content of complex heterogeneous macromolecular organic compounds rich in aromatics, while DOM in all other samples exhibited lower SUVA 254 values (1.0-$3.8 \mathrm{~L} \mathrm{mg}^{-1} \mathrm{C} \mathrm{m}^{-1}$ ), implying a wide range of DOM characteristics and molecular weights [32].

All surface waters were then analysed using EEM fluorescence spectroscopy as previously described $[36,37]$. Spatial and temporal variations of DOM quality were highlighted according to hydrological conditions [32]. The higher concentrations of fluorescent materials were found for waters collected in 2011 (low water) in comparison to those sampled in 2012 (low water) and in 2013 (flooding). The HIX [35] and BIX [36] indices were calculated to gain information on DOM origin and transformation. The highest HIX values, corresponding to aromatic and mature organic material, were observed in the Oise basin with maxima in the forest zones $(\geq 20)$. A relatively high biological activity (BIX $>0.6)$ characterised all the samples, the highest values $(\mathrm{BIX}>0.75)$ being observed for the Seine River in 2011 and 2012 and in the Marne River basin in 2012. The flood period (2013) was characterised by high HIX values (mainly $\geq 10$ ), while the lowest values were observed during the low-water stage (2012), mainly associated with high BIX values, indicating a strong biological activity for these samples [32].

A seven-component model was determined by PARAFAC analysis, explaining $99.8 \%$ of the total data set (102 surface water samples) variability [32]. The EEM spectra contour plots of the seven components are given Fig. 3 (top). The seven components determined showed similarities, with peaks identified in previous studies and related in the literature [32]. Components 4, 5, 6 and 7 were related to biological activity, while components 1,2 and 3 to aromatic and mature terrestrial material ( $\mathrm{C} 1$ and $\mathrm{C} 2$ being mainly linked to aromaticity).

The distributions of these components within the different subbasins and according to the sampling periods are given in Fig. 3 (bottom). Three types of OM were distinguished, the Seine River sub-catchment being mainly characterised by the strongest biological activity, the Oise River subbasin by more terrestrial signatures (even more pronounced for samples taken from forest areas) and a part of the Marne River basin by a third specific type of OM, with a higher contribution of component 7 in particular.

The highest biological signature determined in the Seine River was for samples collected downstream from Paris, pointing out the impact of urban discharges on DOM properties [32]. Moreover, mature DOM of terrestrial origin characterised the samples collected during the flood, while samples collected in the Seine River and the Marne River subbasins during low-water periods (2011 and 2012) were composed of constituents derived from biological activity. However, at low water, a terrestrial signature still described the Oise River sub-catchment. Furthermore, during the flood period, a similar distribution of the seven components was observed for all the samples, whatever the river subbasin, demonstrating a predominant source of terrigenous DOM in the entire watershed. 

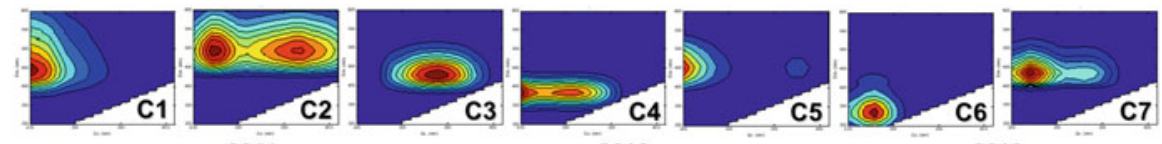

2011

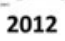

2013
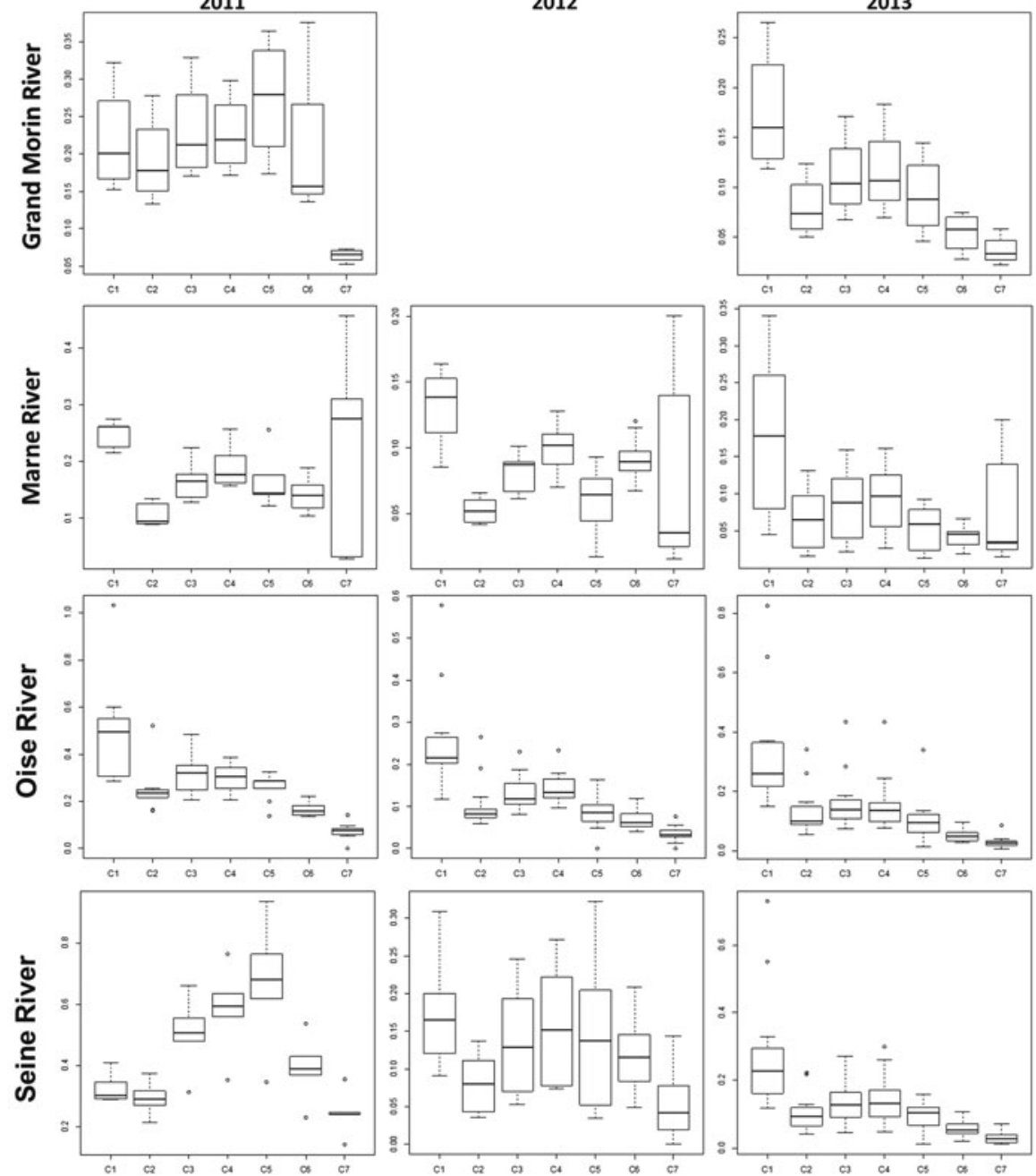

Fig. 3 (Top) EEM contour plots of the seven components identified by PARAFAC C1, C2 and C3, from terrestrial origin, humification process; $\mathrm{C} 4-\mathrm{C} 7$, from biological activity, autochthonous biological/microbial origin. (Bottom) Distribution of the components horizontally, river basin, and vertically, sampling period (2011 and 2012 low water, 2013 high water). Fluorescence intensities in Raman units

Both qualitative and quantitative variations of DOM were thus related to hydrological conditions (flood, low water) and specific geographical locations. The results obtained with the various DOM characterisation tools used in this study are 


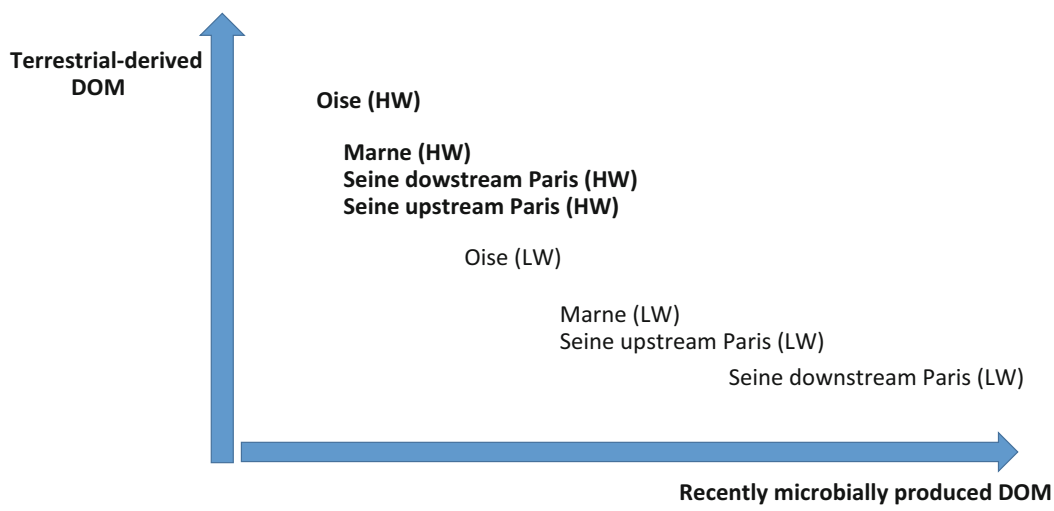

Fig. 4 Origin of DOM in the various watersheds at high water (HW) and low water (LW) according to the different DOM characterisation tools used in this study

consistent and highlight that, overall, during high water, DOM presents a greater contribution of DOM from terrigenous origin, especially for Oise River. In low-water periods, the proportion of DOM from terrestrial origin is significantly lower with a higher relative contribution of recently microbially produced dissolved organic matter, which seems to indicate a recent production of autochthonous DOM and/or a contribution from effluent DOM (EfDOM) especially in the Seine River downstream Paris (Fig. 4). At low water, greater differences in the properties of DOM were observed between the three river subbasins.

\subsection{Impact of the Paris Conurbation Discharges on DOM Quantity and Quality in the Seine River}

Monthly monitoring was carried out over a 1-year period upstream (Upstream I and II sites) and downstream ("Downstream" site) of the Paris agglomeration in order to highlight the impact of the urban discharges on the DOM of the Seine River in terms of both quality and quantity. The water quality parameters measured are presented elsewhere [38]. Throughout the campaign, DOC concentrations at the Upstream I and II sites are very close and follow the same trend: they range from 1.5 to $3.3 \mathrm{mgC} \mathrm{L}{ }^{-1}$, and in both cases, the maximum DOC value is reached during the high-water period in November and January and is correlated with the flow increase. This suggests that this OM originates in part from runoff on the soil and/or erosion from the degrading litter, which is abundant at this period on the banks.

At the downstream site, DOC concentrations were higher than those observed upstream of the agglomeration and varied between 2.5 and $4.5 \mathrm{mgC} \mathrm{L}^{-1}$. This is most likely due to urban discharges from the urban area. It can be highlighted that the DOC concentration differences between downstream and upstream sites are related to river flow and therefore to the dilution of Paris metropolitan area WWTP discharges $\left(23 \mathrm{~m}^{3} \mathrm{~s}^{-1}\right.$ for SIAAP stations). During the high-flow period 
$\left(950 \mathrm{~m}^{3} \mathrm{~s}^{-1}\right)$, the DOC increase at the downstream site compared to the upstream sites was less than $0.5 \mathrm{mgC} \mathrm{L}^{-1}$, while it reached $1.5 \mathrm{mgC} \mathrm{L}^{-1}$ during periods of low water $\left(100-200 \mathrm{~m}^{3} \mathrm{~s}^{-1}\right)$. These values are fully consistent with DOC concentrations in the range of $10-15 \mathrm{mgC} \mathrm{L}^{-1}$ in treated effluent from the Seine-Aval WWTP.

Regarding the DOC distribution between HPI, TPI and HPO fractions at upstream and downstream sites, a high temporal variability can be observed. Indeed, the hydrophobic fraction (HPO) exceeded 60\% in November when soil runoff and leaching started again and then decreased during winter floods (45\% of the DOC). The lowest values, less than $30 \%$, were observed during low-water periods due to autochthonous production as well as the lower terrigenous input. The spatial variability between the upstream and downstream sites is quite clear: the HPI fraction accounts for about 50\% of DOC in low water (between March and September 2011) at the downstream site and only around $40 \%$ at upstream sites. This increase of the HPI fraction at the downstream site is probably due to effluent dissolved organic matter (EfDOM) from WWTPs.

From these data, instantaneous DOC fluxes and DOC flux distribution according to the HPO, TPI and HPI fractions were determined. For each sampling campaign, the DOC flux increased across the Paris conurbation, but the higher increase was noted during low-water periods (from March to September): the DOC flux increase was on average $100 \%, 140 \%$ for the HPI fraction and $75 \%$ for both HPO and TPI fractions. This means that in the receiving environment downstream of the agglomeration, during low-water periods, 50\% of the DOC came from EfDOM, and this proportion reached nearly $60 \%$ for HPI DOC.

This increase in DOC flux through the Paris conurbation area was greater during low-water periods due to the lower dilution of EfDOM. This flux increase was particularly high for the HPI fraction, which is fully consistent with the distribution of DOC observed in EfDOM [29]. These results therefore demonstrate that, even with the very significant improvement in wastewater treatment over the past 50 years, EfDOM of the Paris conurbation remains a very important DOM source for the Seine River. It has a very strong impact on DOM present downstream, both in terms of quantity and quality, causing a significant increase in hydrophilicity downstream of the agglomeration.

\section{Influence of Organic Matter on the Fate of Micro-pollutants and the Role Played by Urban Organic Matter}

\subsection{Context}

In receiving waters, DOM is a key component of both trace metal speciation [10] and bioavailability [11, 39]. Many studies have highlighted the trace metal-binding ability of DOM in surface waters $[10,11,40]$, yet the majority of published works generally concern either the DOM collected from surface waters not affected by 
urbanisation or humic substances (HS), as isolated from natural waters. HS represent the hydrophobic acid fraction of DOM [41] and typically constitute 40-60\% of DOC in most natural surface waters [42-44]. However, in rivers under strong urban pressure such as the Seine River in the Paris conurbation, the proportion of the HPO fraction of DOM decreases as a result of various urban discharges, and the HPI fraction can increase to $50 \%$ of DOC, as was shown in the previous section.

At the beginning of this study, very little information focusing specifically on trace metal binding by HPI DOM in freshwater was available in the literature, most likely due to the difficulty of its isolation and purification. The aim of this study was to determine trace metal-binding parameters of EfDOM from WWTPs, most particularly its HPI fraction, in order to improve the knowledge of metal speciation and bioavailability within aquatic systems under strong urban pressure.

The study of metal complexation by EfDOM and by DOM from receiving water under high urban pressure was conducted in two phases. In the first phase, DOM was fractionated according to its polarity into HPO, TPI and HPI fractions [45, 46]. In this first phase, lead, mercury and zinc [47-49] complexation by the different DOM fractions was studied. Unfortunately, this very time-consuming method can only be applied to a small number of samples, which makes it difficult to characterise DOM spatio-temporal variability in receiving waters.

For this reason, in the second phase, we decided to no longer fractionate DOM so that the complexing properties of the urban DOM could be investigated for a larger number of samples and then the DOM spatio-temporal variability taken into account. Only copper complexation was studied $[29,38]$ in this second phase, focusing on the role of EfDOM from WWTPs in copper speciation and bioavailability in receiving waters across the Paris conurbation.

Furthermore, DOM can play an important role in the sorption/desorption of pollutants on suspended solids in aquatic environments. Indeed, there may be (1) competition between DOM and pollutants for adsorption on the particle surface [50], (2) DOM can also clog the particles pores and thus limit pollutant adsorption [51-53], (3) by adsorbing on particles, DOM can modulate their pollutant binding ability [54] and (4) DOM can also bind pollutants and therefore maintain them in solution or, on the other hand, make it easier for them to adsorb as they are associated with DOM [55, 56]. These interactions may depend on the quality of the DOM. EfDOM and DOM of terrigenous origin could therefore have a different effect on the pollutant sorption onto particles. In this study [57], the effect of EfDOM or fulvic acid onto adsorption of PAHs and trace metals was studied.

\subsection{Material and Methods}

\subsubsection{Sampling Points}

To collect EfDOM, seven campaigns were conducted at the Seine-Aval WWTP (see Fig. 1), which collected, in 2012, over $70 \%$ of dry weather flows from the Paris conurbation (six million inhabitants). These effluents accounted for more than $80 \%$ 
of the effluent dissolved organic carbon discharged into the Seine River from the entire conurbation, thus offering highly representative samples. Treatment consisted of primary settling for suspended solid removal, aerobic activated sludge for carbon removal and biofilters for nitrogen removal (nitrification and denitrification).

To characterise the spatial evolution of DOM trace metal complexation parameters in receiving waters throughout the Paris conurbation, three sampling sites (labelled Downstream and Upstream I and II) were selected (see Sect. 2.2 and Fig. 1). Five sampling campaigns were carried out at these three sites during both the high-flow period (November 2010 to January 2011) and low-flow period (March 2011, June 2011 and September 2011).

A standard fulvic acid (Suwannee River Fulvic Acid, SRFA 2S101F), purchased from the International Humic Substances Society, was used as a "natural organic matter" reference for follow-up investigations relative to DOM influence on copper bioavailability and pollutant adsorption onto particles.

\subsubsection{Experimental Procedures}

Experimental procedures concerning (1) sample treatment; (2) characterisation of copper-, lead-, zinc- and mercury-binding abilities; and (3) characterisation of DOM influence on copper bioavailability as well as the methodology used for trace metal speciation modelling are given in several publications [29, 38, 47-49].

Concerning the influence of the DOM type on pollutant adsorption, experimental procedures are described elsewhere [57]. Briefly, EfDOM or SRFA $\left(10 \mathrm{mgC} \mathrm{L}^{-1}\right)$ and particles $\left(0-5,000 \mathrm{mg} \mathrm{L}^{-1}\right.$ of montmorillonite, goethite or quartz) were mixed for $72 \mathrm{~h}$. Seven metals ( $\mathrm{Cd}, \mathrm{Co}, \mathrm{Cu}, \mathrm{Ni}, \mathrm{Pb}, \mathrm{V}$ and $\mathrm{Zn}$ ) as well as As were then added, and the whole was left in equilibrium for $72 \mathrm{~h}$. Trace metal concentrations were around $1 \mu \mathrm{mol} \mathrm{L}{ }^{-1}$ except for cadmium $\left(0.1 \mu \mathrm{mol} \mathrm{L}^{-1}\right)$. Tubes were centrifuged at a relative centrifugal field of $4,000 \times g$ for $60 \mathrm{~min}$. Supernatant solutions were filtered through a $0.45-\mu \mathrm{m}$ polypropylene filter, and the total dissolved metal concentration was determined by ICP-AES in order to deduce the proportion of adsorbed metals. Another aliquot was filtered through a chelating disc $\left(\right.$ Chelex $\left.100^{\circledR}\right)$ to distinguish between labile complexes (mainly mineral) and inert complexes (mainly organic) [58]. The control was processed without DOM.

Adsorption of six PAHs - pyrene (Pyr), benzo[a]anthracene (B[a]A), chrysene (Chry), benzo[b]fluoranthene $(\mathrm{B}[\mathrm{b}] \mathrm{F})$, benzo[k]fluoranthene $(\mathrm{B}[\mathrm{k}] \mathrm{F})$ and benzo[a] pyrene $(\mathrm{B}[\mathrm{a}] \mathrm{P})$ - were studied with the same procedure.

\subsection{Characterisation of DOM Trace Metal-Binding Ability}

\subsubsection{Binding Site Modal Distribution}

For the sake of simplicity, in the bimodal distribution of binding site stability constants, the modal distribution with a lower stability constant was labelled " $\mathrm{L}_{1}$ ", 
and the modal distribution with the higher stability constant was labelled " $\mathrm{L}_{2}$ ". $\mathrm{L}_{1}$ sites could correspond to carboxylic-type groups and $\mathrm{L}_{2}$ sites to phenolic-type groups, although the reality is much more complex [59].

For copper and lead complexation by DOM from receiving waters, the trace metal complexation was modelled with a bimodal distribution, in accordance with the literature [60]. Whereas for their complexation by EfDOM, a trimodal binding site distribution proved to be more suitable [29, 47]. In the case of copper, there is a very high-affinity site type $\left(\mathrm{L}_{3}\right)$, in addition to the typical low- $\left(\mathrm{L}_{1}\right)$ and high-affinity sites $\left(\mathrm{L}_{2}\right)$. For lead, this is a third modal distribution corresponding to sites with an intermediate stability constant between stability constants of low- and high-affinity sites. This third family of binding sites could be associated with proteinic structures, amines and amide groups present in the hydrophilic fraction of EfDOM [61]. Some of these binding sites might also be associated with amino polycarboxylates, phosphonates and hydroxycarboxylates [62].

In contrast, for zinc, a bimodal distribution was suitable for all DOM fractions including EfDOM, whereas for mercury only one site type was obtained for all DOM fractions. This single site is usually associated with reduced $\mathrm{N}$ (amide, amine) and especially $\mathrm{S}$ (thiol) groups of proteinic structures and, to a lesser extent, with carboxylic groups.

\subsubsection{Me-DOM Stability Constants and Binding Site Density}

In the case of copper complexation at $\mathrm{pH} 8$, for the five campaigns in receiving waters and seven campaigns for EfDOM, the conditional stability constants ranged from $10^{7.3} \mathrm{M}^{-1}$ to $10^{7.9} \mathrm{M}^{-1}$ for low-affinity sites $\left(\mathrm{L}_{1}\right)$ and from $10^{10.2} \mathrm{M}^{-1}$ to $10^{11.2} \mathrm{M}^{-1}$ for high-affinity sites $\left(\mathrm{L}_{2}\right)$, and no significant difference was found across the various sampling points; moreover, no temporal variations in stability constant were observed.

The $\mathrm{L}_{1}$ copper-binding site density values were similar between upstream sites in receiving waters $(\approx 1 \mathrm{~mol}$ of binding sites per $\mathrm{kg}$ of organic carbon) and higher than for $\operatorname{EfDOM}\left(\approx 0.5 \mathrm{~mol} \mathrm{~kg}^{-1}\right)$. The $\mathrm{L}_{2}$ binding site density values were lower than for $\mathrm{L}_{1}$ binding sites with equivalent values for receiving waters and EfDOM, ranging from 0.1 to $0.3 \mathrm{~mol} \mathrm{~kg}{ }^{-1}$. EfDOM presented by far the lowest $\left(\mathrm{L}_{1} / \mathrm{L}_{2}\right)$ ratio, with an average value, equal to 2.7 , much smaller than those obtained for receiving water DOM, whose average ratio varied between 7.3 and 7.9. In the case of lead, the $L_{1} / L_{2}$ ratio value was 7.3 for receiving waters and reached only 0.7 for the EfDOM fractions. Even more than in the case of copper, a higher presence of high-affinity binding sites was noted in EfDOM fractions compared to receiving water DOM. The total lead-binding site density was much higher for the HPI EfDOM fraction compared to other EfDOM and downstream fractions.

In the case of very high-affinity $\left(\mathrm{L}_{3}\right)$ copper-binding sites that were highlighted only for EfDOM, conditional stability constants ranged from $10^{12.2} \mathrm{M}^{-1}$ to $10^{13.6} \mathrm{M}^{-1}$. The $\mathrm{L}_{3}$ site density (mean, $5.7 \times 10^{-2} \mathrm{~mol} \mathrm{~kg}^{-1}$ ) was less than $\mathrm{L}_{2}$ and $\mathrm{L}_{1}$ densities; it amounted to between $25 \%$ and $33 \%$ of the $\mathrm{L}_{2}$ density. The $\mathrm{L}_{3}$ 
binding site concentration was slightly less than $10^{-6}$ mol L ${ }^{-1}$ in Seine-Aval WWTP effluent. Even if it was lower than those of $\mathrm{L}_{1}$ and $\mathrm{L}_{2}$ sites, it was environmentally relevant given that trace metal concentrations in receiving waters were considerably lower, ranging from $10^{-10}$ to $10^{-7} \mathrm{~mol} \mathrm{~L}^{-1}$.

For zinc, there was not a very-high-affinity site but, regardless of the sampling site (receiving waters or EfDOM), the HPI fraction could systematically be characterised by higher stability constants $\left(\mathrm{K}_{1}\right.$ and $\left.\mathrm{K}_{2}\right)$ and a lower $\mathrm{L}_{1} / \mathrm{L}_{2}$ ratio compared to the other fractions [49].

Regarding mercury, stability constants for EfDOM fractions $\left(10^{25.2} \mathrm{M}^{-1}\right)$ were significantly higher than for the SRFA standard $\left(10^{22.8} \mathrm{M}^{-1}\right)$ but roughly equal to those observed for the Upstream I site DOM fractions $\left(10^{24.6} \mathrm{M}^{-1}\right)$ [48]. In both cases, no significant differences were observed depending on the different fractions. Furthermore, it has been shown that stability constants are positively correlated with total organic $\mathrm{N}$ and $\mathrm{S}$. N- and S-enriched organic materials, such as EfDOM, had stronger Hg-complexing ligands [48].

Overall, these results highlight the strong binding capacity of EfDOM. The high binding ability of EfDOM and especially its HPI fraction could be explained by their nitrogen and sulphur group contents [47-49]. It could be noted that EfDOM revealed a high trace metal-binding ability despite its low aromaticity, as indicated by its low SUVA [29].

\subsection{Contribution of EfDOM from Seine-Aval WWTP to the Copper-Binding Site Flux in the Seine River Downstream of Paris}

During the low-water period, the copper-binding site molar concentrations in the Seine River evolved significantly from upstream to downstream of Paris, with an increase of $173 \%$ for $L_{1}$ sites and $157 \%$ for $L_{2}$ sites [29]. This increase was probably due to EfDOM discharges in the receiving waters. $L_{1}$ and $L_{2}$ site concentrations in EfDOM were, respectively, three times and ten times higher than in upstream waters [29]. Based on the experiments carried out in the Piren-Seine programme, the contribution of EfDOM from the Seine-Aval WWTP to the binding site fluxes in receiving water downstream of the Paris conurbation was assessed [29].

The ratio of binding sites originating from EfDOM to total binding sites measured downstream of Paris was calculated as described in [29]. This instantaneous flux ratio was calculated for all sampling dates (Fig. 5).

During high-flow periods, the contribution of EfDOM from the WWTP SeineAval to the total binding site concentration at the downstream site was around 5\% and $23 \%$, respectively, for low-affinity $\left(\mathrm{L}_{1}\right)$ and high-affinity $\left(\mathrm{L}_{2}+\mathrm{L}_{3}\right)$ sites. Due to the lower EfDOM dilution, during the low-flow period, these averaged values were two to five times higher, i.e. reaching $19 \%$ and $58 \%$, respectively. Downstream of Paris, during the low-water period, the largest proportion of high-affinity binding 
Fig. 5 Seine River flow at Paris Austerlitz and temporal variations in the percentage of the $\mathrm{Cu}$-binding site flux (L1, top; and L2 + L3, bottom) at the downstream site originating from EfDOM. Figure reproduced from Fig. 3 in Ref. [29]

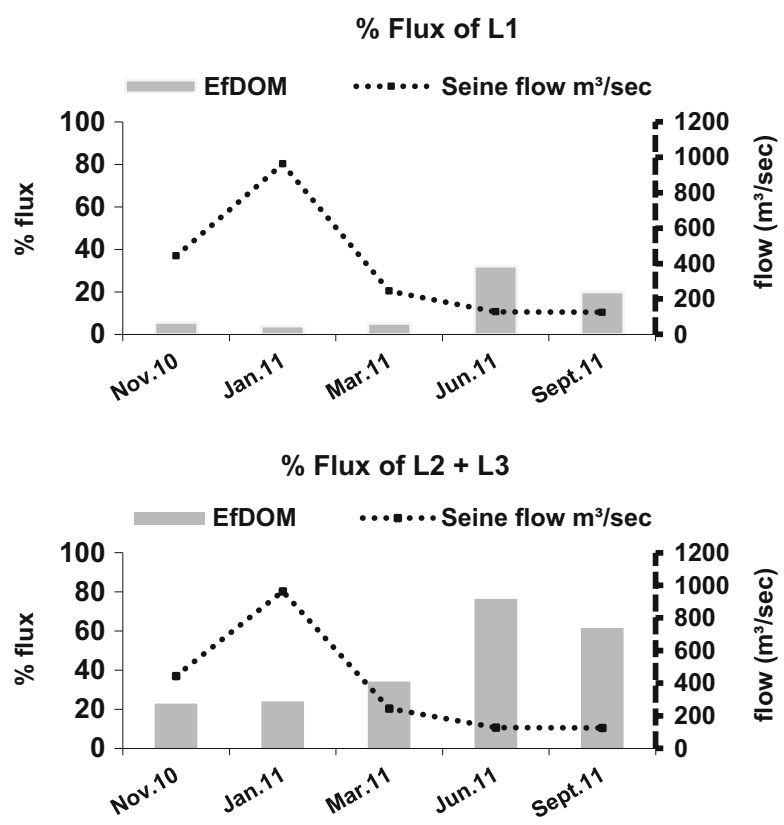

sites stems from EfDOM; the other smaller portion originates from upstream of Paris. Downstream of Paris, the percentages of high-affinity binding sites $\left(\mathrm{L}_{2}+\mathrm{L}_{3}\right)$ originating from EfDOM are much greater than those of low-affinity binding sites $\left(\mathrm{L}_{1}\right)$, which underscores the strong impact, especially during low-flow periods, of urban discharges on the high-affinity binding site concentration downstream of Paris.

\subsection{Modelling of Trace Metal Speciation in the Seine River Upstream and Downstream of the Paris Conurbation}

To assess the environmental implications relative to the strong metal-binding ability of EfDOM, metal speciation was computed in the Seine River upstream and downstream of the Seine-Aval WWTP discharge point. Binding parameters experimentally determined in works carried out within the Piren-Seine programme [29, 47-49] were used to conduct the computation. The competition of metal with other trace metals or major elements for DOM complexation was not taken into account. The $\mathrm{pH}$ was either set at 8, which is the known $\mathrm{pH}$ value for the Seine River, or 6.8, which accounts for the DOM-induced $\mathrm{pH}$ value in Hg-DOM stability constant assessment tests. The complete methodology for modelling is presented elsewhere [29, 47-49]. 
In the case of $\mathrm{Hg}$, the distribution of dissolved $\mathrm{Hg}$ among the three different DOM fractions was calculated in receiving waters at the Upstream I site, in EfDOM and in receiving waters considering different dilution factors $(\alpha)$ of EfDOM in the Seine River (Table 1).

The Hg-DOM from Upstream I consisted of 94\% $\mathrm{Hg}$-HPO, 5\% $\mathrm{Hg}$-TPI and $0.7 \%$ $\mathrm{Hg}$-HPI. For EfDOM, these percentages were 25\% $\mathrm{Hg}$-HPO, 22\% $\mathrm{Hg}$-TPI and 53\% $\mathrm{Hg}-\mathrm{HPI}$. After dilution of EfDOM in Upstream I water, the $[\mathrm{Hg}-\mathrm{DOM}]_{\mathrm{EfDOM}}$ : $[\mathrm{Hg}-\mathrm{DOM}]_{\text {Upstream I }}$ ratio values decreased from 19 down to 2.3 and 0.8 , respectively, for a dilution of 4,25 and 80 , respectively. As regards the $[\mathrm{Hg}-\mathrm{HPI}]_{\mathrm{EfDOM}}$ :

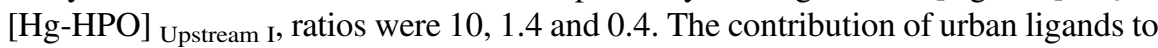
[Hg-DOM] of mixed EfDOM and Upstream I waters decreased from 95\%, 70\% down to $43 \%$, respectively.

For other trace metals, we obtained the same type of results. For copper, inorganic copper and free copper were both more abundant upstream of Paris, where free copper exceeded the downstream value by a factor of 2-4 [29]. This result was probably due to the higher complexing affinity of DOM downstream of Paris, as previously highlighted.

In the case of zinc, downstream of Paris, at the low-water period and therefore low EfDOM dilution, roughly $49-94 \%$ of total zinc was bound to the EfDOM HPI fraction, mainly through $\mathrm{L}_{2}$ sites at 10 and $1 \mu \mathrm{g} \mathrm{L}^{-1}$ total dissolved zinc concentration, respectively. EfDOM and especially the HPI fraction therefore controlled zinc speciation in the Seine downstream of Paris to a large extent. It can be highlighted that the presence of EfDOM downstream of Paris decreases the percentage of free zinc by a factor ranging from 1.8 at $[\mathrm{Zn}]_{\text {total }}=10 \mu \mathrm{g} \mathrm{L}^{-1}$ to 12 at $[\mathrm{Zn}]_{\text {total }}=1 \mu \mathrm{g} \mathrm{L}^{-1}$.

Table 1 Modelled dissolved Hg partition between Upstream I site DOM and EfDOM considering different dilution factors of EfDOM in the Seine River

\begin{tabular}{l|l|l|l|l|l}
\hline \multirow{4}{*}{$\begin{array}{l}\text { Type of } \\
\text { DOM }\end{array}$} & \multirow{4}{*}{$\begin{array}{l}\text { DOM fraction and } \\
\text { DOM types under various water dilution conditions }\end{array}$} \\
\cline { 3 - 6 } & $\begin{array}{l}\alpha=1 \text { (prior } \\
\text { total contribution }\end{array}$ & $\begin{array}{l}\alpha=4 \text { (low } \\
\text { to dilution) }\end{array}$ & $\begin{array}{l}\alpha=25 \\
\text { (mean } \\
\text { waters) }\end{array}$ & $\begin{array}{l}\alpha=80 \\
\text { dilution) }\end{array}$ & $\begin{array}{l}\text { high } \\
\text { waters) }\end{array}$ \\
\hline \multirow{2}{*}{$\begin{array}{l}\text { Upstream I } \\
\text { site DOM }\end{array}$} & HPO & $94 \pm 7$ & $5 \pm 1$ & $28 \pm 2$ & $54 \pm 4$ \\
\cline { 2 - 6 } & TPI & $5 \pm 1$ & $0.3 \pm 0.2$ & $1.0 \pm 0.7$ & $3 \pm 1$ \\
\cline { 2 - 6 } & HPI & $0.7 \pm 0.5$ & $<0.1$ & $0.2 \pm 0.1$ & $0.4 \pm 0.2$ \\
\cline { 2 - 6 } & Total & 100 & $5 \pm 2$ & $30 \pm 3$ & $57 \pm 6$ \\
\hline EfDOM & HPO & $25 \pm 3$ & $24 \pm 2$ & $18 \pm 1$ & $11 \pm 1$ \\
\cline { 2 - 6 } & TPI & $22 \pm 2$ & $20 \pm 1$ & $15 \pm 1$ & $9 \pm 1$ \\
\cline { 2 - 6 } & HPI & $53 \pm 4$ & $51 \pm 3$ & $38 \pm 3$ & $23 \pm 2$ \\
\cline { 2 - 6 } & Total & 100 & $95 \pm 7$ & $70 \pm 6$ & $43 \pm 5$ \\
\hline
\end{tabular}

Data were obtained using laboratory conditions with experimentally determined stability constants and binding site density values 
Concerning lead, the results highlighted that between $82 \%$ and $90 \%$ of $\mathrm{Pb}$ is bound to the EfDOM HPI fraction, overcoming by a wide margin the complexation to the river HPO fraction (humic substances) [47].

Despite the uncertainties, it has been demonstrated in this work that dissolved organic matter contained in WWTP-treated effluents and particularly its hydrophilic fraction, due to their very high complexing properties, can control a large proportion of the dissolved trace metal speciation downstream of the Paris conurbation, particularly in low-water periods because of low EfDOM dilution.

\subsection{Evaluation of the Role of DOM on Copper Bioavailability Toxicity to Daphnia magna}

The median effective concentration (EC50) values are the toxic concentration for $50 \%$ of a population of Daphnia magna. They are expressed in total dissolved copper concentration $\left(\mathrm{EC} 50_{\text {tot }}\right)$ for each DOM studied and for the inorganic matrix (Fig. 6). Compared with tests conducted in the inorganic matrix, the $\mathrm{EC} 50_{\text {tot }}$ values were systematically higher in the presence of DOM. By binding copper, DOM actually reduced its bioavailability and therefore caused an EC50 increase to higher concentrations. This outcome was very consistent with the literature, which describes the role of organic matter in reducing the toxicity of metals [63-67].

Statistically significant differences (by a factor of 2) in $\mathrm{EC} \mathrm{O}_{\mathrm{tot}}$, depending on the type of DOM, were observed. DOM originating upstream of Paris displayed significant differences with the lower $\mathrm{EC} 50_{\text {tot }}$ value for Upstream II when compared to Upstream I. The Upstream I value was comparable to those obtained for the Suwannee River Fulvic Acid (SRFA) and for downstream site. A slightly higher $\mathrm{EC} 0_{\text {tot }}$ was found for EfDOM, which confirms the influence of EfDOM in reducing copper toxicity $[29,39]$. As opposed to what has been observed in natural waters [65], no positive correlation could be derived either between EC50 tot and SUVA of

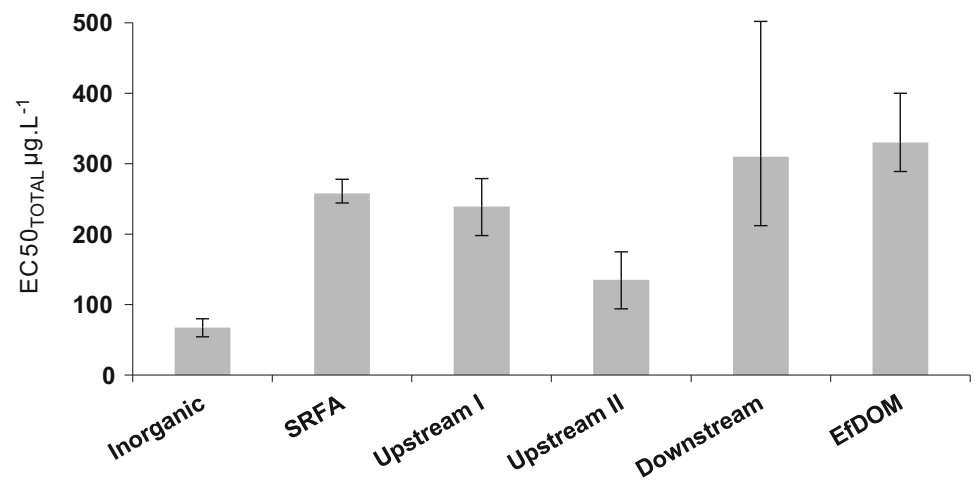

Fig. 6 EC50 expressed in dissolved total copper concentrations, for each DOM studied, SRFA and the inorganic matrix. Figure reproduced from Fig. 4 in Ref. [29] 
DOM, which acts as a good proxy for DOM aromaticity, or between EC50 tot and the DOM aromaticity percentage [29, 49]. The highest EC50 tot values, however, were observed for EfDOM with very low aromaticity and a low UV absorbance. Compared to DOM from Upstream I and II, EfDOM and Downstream DOM presented higher densities of high-affinity binding sites $\left(\mathrm{L}_{2}\right)$ and even very high-affinity binding sites $\left(\mathrm{L}_{3}\right)$ for EfDOM, which may be responsible for the greater protective role played by these DOM samples.

Logically, given the strong affinity of EfDOM for copper, these results prove that EfDOM has a considerable influence on copper toxicity on Daphnia magna with a slightly greater protecting effect than both SRFA and DOM from upstream of Paris.

\subsection{Effect of EfDOM on Trace Metal Sorption by Mineral Particles in Aquatic Systems Subjected to Strong Urban Pressure}

The results obtained showed that in many cases trace metal adsorption onto montmorillonite (MMT) and goethite was strongly modified by DOM compared to the control without DOM [57]. In the case of adsorption onto MMT, there was no influence of the DOM type on copper adsorption, with a $65 \%$ decrease with both EfDOM and SRFA. The adsorption decrease for $\mathrm{Zn}$ was $17 \%$ with SRFA and reached $60 \%$ with EfDOM. Given the very large increase of inert complexes in the dissolved fraction $(+200 \%)$ with EfDOM compared to SRFA, it would appear that the substantial $\mathrm{Zn}$ adsorption decrease with EfDOM is due to maintaining $\mathrm{Zn}$ in solution by complexation with EfDOM. As for $\mathrm{Zn}, \mathrm{Cd}$ was weakly adsorbed on MMT in the presence of EfDOM due to its retention in solution as inert complexes with EfDOM.

In the case of adsorption onto goethite, the Cd adsorption with SFRA was higher compared to the control $(+162 \%)$, while it was lower in the presence of EfDOM $(-20 \%)$. Zn showed a similar behaviour, while for As, adsorption was lower with DOM, especially with EfDOM (-65\%). For $\mathrm{Cu}$ and Ni, adsorption with SRFA was similar to that of the control, while it decreased by $54 \%$ and $77 \%$, respectively, with EfDOM. For $\mathrm{Cd}$, $\mathrm{Ni}$ and $\mathrm{Zn}$, the sorption decrease is probably due to maintaining in solution by complexation with EfDOM.

\subsection{Effect of EfDOM on PAH Adsorption by Mineral Particles in Aquatic Systems Subjected to Strong Urban Pressure}

Adsorption of six PAHs, pyrene (Pyr), benzo[a]anthracene (B[a]A), chrysene (Chry), benzo[b]fluoranthene $(\mathrm{B}[\mathrm{b}] \mathrm{F})$, benzo[k]fluoranthene $(\mathrm{B}[\mathrm{k}] \mathrm{F})$ and benzo[a] 


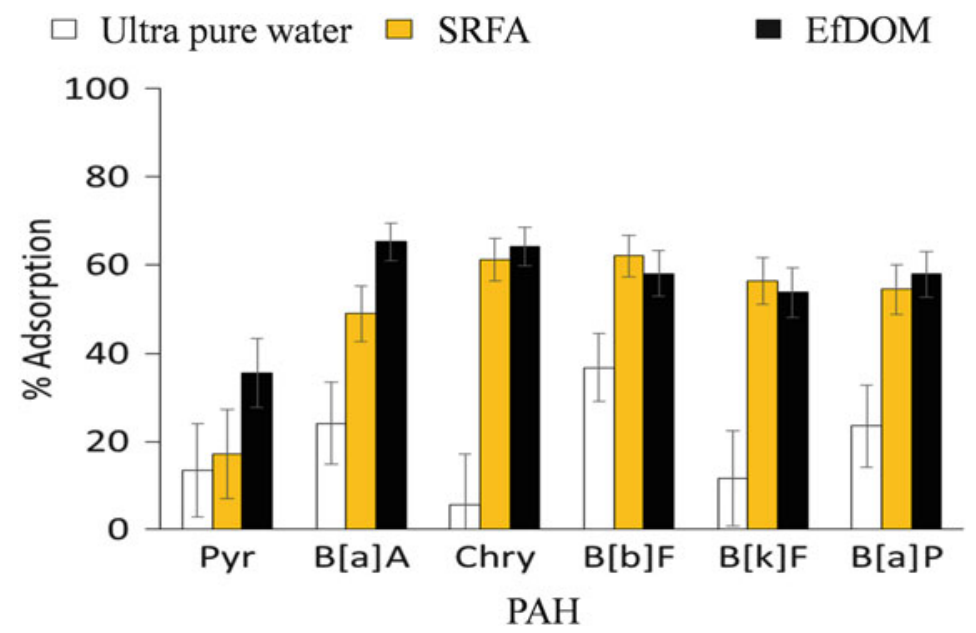

Fig. 7 Adsorption of PAH $\left(250 \mathrm{ng} \mathrm{L}^{-1}\right)$ classified from lowest to highest molecular weight onto quartz $\left(500 \mathrm{mg} \mathrm{L}^{-1}\right)$ in ultrapure water and with EfDOM $\left(10 \mathrm{mgC} \mathrm{L}^{-1}\right)$ or SRFA $\left(10 \mathrm{mgC} \mathrm{L}^{-1}\right)$. Figure reproduced from Fig. 75 in Ref. [57]

pyrene $(\mathrm{B}[\mathrm{a}] \mathrm{P})$ onto MMT, goethite and quartz were studied in ultrapure water and with SRFA or EfDOM [57].

In ultrapure water, the adsorption of PAH onto MMT is higher than for other particles in the order MMT > goethite > quartz. With DOM, the adsorption varied according to the nature of DOM, the mineral phase and the properties of the PAHs (Fig. 7).

Concerning MMT, PAH adsorption was lower with DOM, especially in the presence of SRFA ( $-25 \%$ to $-70 \%)$ compared to EfDOM ( -10 to $-50 \%)$.

For goethite, the presence of SRFA mainly reduced the adsorption of light PAHs (Pyr and B[a]A) by about $60 \%$, while the absorption decrease is only about $20 \%$ for heavier PAHs (Chry, B[b]F, B[k]F, B[a]P). With EfDOM, the adsorption decrease is about $40-70 \%$ regardless of PAH molecular weight.

For quartz, unlike goethite and MMT, adsorption increased as DOM increased. The very low PAH adsorption in ultrapure water was increased by about $50 \%$ for B [b]F and pyrene to a factor of 5 for Chry and B[k]F. The differences in PAH adsorption on quartz depending on the type of DOM were not statistically significant, and therefore the sorption increase did not seem to depend here on the DOM quality.

\section{Conclusions and Perspectives}

The spatio-temporal variability of aquatic OM composition in the Seine River watershed upstream and downstream of Paris Megacity and its effect on micropollutant speciation and fate have been widely studied, especially since 2010 , within 
the PIREN-Seine programme. Both qualitative and quantitative variations of DOM have been related to hydrological conditions and specific geographical locations. Furthermore, it has been demonstrated that EfDOM of the Paris conurbation, despite the very significant improvement in wastewater treatment over the past 50 years, had a very strong impact on DOM present downstream, both in terms of quantity and quality, causing a significant increase in hydrophilicity downstream of the agglomeration.

With regard to speciation and bioavailability of dissolved metals, these studies have demonstrated the strong trace metal-binding ability of EfDOM in spite of its low aromaticity. The remarkably high binding ability of EfDOM and especially of its HPI fraction could be explained by its proteinic nature as well as high nitrogen and sulphur group contents. Through modelling, it has been demonstrated that EfDOM, due to their very high complexing properties, can control, to a large degree, the dissolved trace metal speciation downstream of the Paris conurbation, particularly in low-water periods because of low EfDOM dilution. These results also highlight that the trace metal speciation computation in surface water subjected to important urban discharges should include not only the humic and/or fulvic part of DOM but also other more hydrophilic fractions as depicted by EfDOM. Logically, given the strong affinity of EfDOM for trace metals, these studies have pointed out that EfDOM had a high influence on copper toxicity to Daphnia magna, with a slightly greater protective effect than one fulvic acid standard and DOM from the upstream Paris conurbation. Much research is still needed, however, in order to fully understand how the shape and molecular structures constitutive of EfDOM molecules favour the interactions between binding moieties and metallic pollutants.

With regard to pollutant-suspended particle interactions, our results highlight that in many cases trace metal and PAH adsorption onto particles was strongly modified in presence of DOM. Furthermore, the DOM influence on pollutant adsorption depends on the DOM type. Hence, in addition to playing a central role in dissolved metal speciation, EfDOM could also influence the pollutant transport in aquatic systems as well as their transfers among aquatic compartments.

The combination of all these results indicates that it is essential to take into account the great spatio-temporal variability of DOM properties to investigate water quality and river system functioning. It also highlights that hydrophilic organic matter from major WWTPs could play an important role in the biogeochemical cycle of pollutants within aquatic systems under strong urban pressure.

Acknowledgements We sincerely thank Dr. Benoit Pernet-Coudrier, assistant professor at the University of Western Brittany, who passed away accidentally in 2016. His PhD work has strongly contributed to the study of interactions between DOM and metals discussed in this chapter. This work was conducted in the framework of the PIREN-Seine research programme (www. piren-seine.fr), a component of the Zone Atelier Seine within the international Long-Term Socio Ecological Research (LTSER) network. 


\section{References}

1. Artifon V, Zanardi-Lamardo E, Fillmann G (2019) Aquatic organic matter: classification and interaction with organic microcontaminants. Sci Total Environ 649:1620-1635

2. Cawley KM, Butler KD, Aiken GR, Larsen LG, Huntington TG, McKnight DM (2012) Identifying fluorescent pulp mill effluent in the Gulf of Maine and its watershed. Mar Pollut Bull 64(8):1678-1687

3. Bauer JE, Bianchi TS (2011) Dissolved organic carbon cycling and transformation. In: Wolanski E, McLusky DS (eds) Treatise on estuarine and coastal science, vol 5. Academic Press, Waltham, pp 7-67

4. Besemer K, Luef B, Preiner S, Eichberger B, Agis M, Peduzzi P (2009) Sources and composition of organic matter for bacterial growth in a large European river floodplain system (Danube, Austria). Org Geochem 40(3):321-331

5. Lambert T, Bouillon S, Darchambeau F, Morana C, Roland FAE, Descy J-P, Borges AV (2017) Effects of human land use on the terrestrial and aquatic sources of fluvial organic matter in a temperate river basin (The Meuse River, Belgium). Biogeochemistry 136:191. https://doi.org/ 10.1007/s10533-017-0387-9

6. Battin TJ, Kaplan LA, Findlay S, Hopkinson CS, Marti E, Packman AI, Newbold JD, Sabater F (2009) Biophysical controls on organic carbon fluxes in fluvial networks. Nat Geosci 1(8):95-100. https://doi.org/10.1038/ngeo101

7. Wiegner TN, Tubal RL, MacKenzie RA (2009) Bioavailability and export of dissolved organic matter from a tropical river during base-and stormflow conditions. Limnol Oceanogr 54(4):1233-1242

8. Stedmon CA, Markager S, Bro R (2003) Tracing dissolved organic matter in aquatic environments using a new approach to fluorescence spectroscopy. Mar Chem 82(3-4):239-254. https:// doi.org/10.1016/S0304-4203(03)00072-0

9. Garnier J, Marescaux A, Guillon S et al (2020) Ecological functioning of the Seine River: from long term modelling approaches to high frequency data analysis. In: Flipo N, Labadie P, Lestel L (eds) The Seine River basin. Handbook of environmental chemistry. Springer, Cham. https:// doi.org/10.1007/698_2019_379

10. Buffle J (1988) Complexation reactions in aquatic system: an analytical approach. Ellis Horwood, New York, p 692

11. Campbell PGC (1995) Interactions between trace metals and aquatic organisms: a critique of the free-ion activity model. In: Tessier A, Turner DR (eds) Metal speciation and bioavailability in aquatic systems. Wiley, Chichester, pp 45-102

12. Bormann FH, Likens GE (1967) Nutrient cycling. Science 155(3761):424-429. https://doi.org/ 10.1126/science.155.3761.424

13. Nebbioso A, Piccolo A (2013) Molecular characterization of dissolved organic matter (DOM): a critical review. Anal Bioanal Chem 405(1):109-124. https://doi.org/10.1007/s00216-0126363-2

14. Amy G, Drewes J (2007) Soil aquifer treatment (SAT) as a natural and sustainable wastewater reclamation/reuse technology: fate of wastewater effluent organic matter (EfOM) and trace organic compounds. Environ Monit Assess 129:19-26. https://doi.org/10.1007/s10661-0069421-4

15. Baghoth SA, Sharma SK, Amy GL (2011) Tracking natural organic matter (NOM) in a drinking water treatment plant using fluorescence excitation emission matrices and PARAFAC. Water Res 45:797-809. https://doi.org/10.1016/j.watres.2010.09.005

16. Lidén A, Keucken A, Persson KM (2017) Uses of fluorescence excitation-emissions indices in predicting water treatment efficiency. J Water Process Eng 16:249-257. https://doi.org/10. 1016/j.jwpe.2017.02.003

17. Bieroza MZ, Bridgeman J, Baker A (2010) Fluorescence spectroscopy as a tool for determination of organic matter removal efficiency at water treatment works. Drinking Water Eng Sci 3:63-70. https://doi.org/10.5194/dwes-3-63-2010 
18. Rocher V, Azimi S (2017) Evolution de la qualité de la Seine en lien avec les progrès de l'assainissement de 1970 à 2015. Editions Johanet, Paris, p 76

19. Billen G, Garnier J, Mouchel J-M, Silvestre M (2007) The Seine system: introduction to a multidisciplinary approach of the functioning of a regional river system. Sci Total Environ 375:1-12. https://doi.org/10.1016/j.scitotenv.2006.12.001

20. Garnier J, Leporcq B, Sanchez N, Philippon (1999) Biogeochemical mass-balances (C, N, P, Si) in three large reservoirs of the Seine Basin (France). Biogeochemistry 47:119-146

21. Garnier J, Billen G (2007) Production vs. respiration in river systems: an indicator of an "ecological status". Sci Total Environ 375:110-124. https://doi.org/10.1016/j.scitotenv. 2006.12.006

22. Thévenot DR, Moilleron R, Lestel L, Gromaire M-C, Rocher V, Cambier P, Bonté P, Colin J-L, de Pontevès C, Meybeck M (2007) Critical budget of metal sources and pathways in the Seine River basin (1994-2003) for Cd, Cr, Cu, Hg, Ni, Pb and Zn. Sci Total Environ 375:180-203. https://doi.org/10.1016/j.scitotenv.2006.12.008

23. Servais P, Garcia-Armisen T, George I, Billen G (2007) Fecal bacteria in the rivers of the Seine drainage network (France): sources, fate and modelling. Sci Total Environ 375:152-167. https://doi.org/10.1016/j.scitotenv.2006.12.010

24. Vilmin L, Flipo N, Escoffier N, Rocher V, Groleau A (2016) Carbon fate in a large temperate human-impacted river system: focus on benthic dynamics. Global Biogeochem Cycles 30:1086-1104. https://doi.org/10.1002/2015GB005271

25. Garnier J, Vilain G, Silvestre M, Billen G, Jehanno S, Poirier D, Martinez A, Decuq C, Cellier P, Abril G (2013) Budget of methane emissions from soils, livestock and the river network at the regional scale of the Seine basin (France). Biogeochemistry 116:199. https://doi. org/10.1007/s10533-013-9845-1

26. Jaffé R, McKnight D, Maie N, Cory R, McDowell WH, Campbell JL (2008) Spatial and temporal variations in DOM composition in ecosystems: the importance of long-term monitoring of optical properties. J Geophys Res 113:G04032. https://doi.org/10.1029/2008JG000683

27. Cory RM, Boyer EW, McKnight DM (2011) Spectral methods to advance understanding of dissolved organic carbon dynamics in forested catchments. In: Levia DF et al (eds) Forest hydrology and biogeochemistry: synthesis of past research and future directions, ecological studies, vol 216. Springer, Cham. https://doi.org/10.1007/978-94-007-1363-5_6

28. Jaffé R, Cawley KM, Yamashita Y (2014) Applications of excitation emission matrix fluorescence with parallel factor analysis (EEM-PARAFAC) in assessing environmental dynamics of natural dissolved organic matter (DOM) in aquatic environments: a review. Chapter 3. Advances in the physicochemical characterization of dissolved organic matter: impact on natural and engineered systems; Rosario-Ortiz, ACS symposium series. American Chemical Society, Washington. https://doi.org/10.1021/bk-2014-1160.ch003

29. Matar Z (2015) Influence of effluent organic matter on copper speciation and bioavailability in rivers under strong urban pressure. Environ Sci Pollut Res 22:19461-19472. https://doi.org/ 10.1007/s11356-015-5110-6

30. Servais P, Barillier A, Garnier J (1995) Determination of the biodegradable fraction of dissolved and particulate organic carbon in waters. Ann Limnol 31(1):75-80

31. Mao J, Cao X, Olk DC, Chu W, Schmidt-Rohr K (2017) Advanced solid-state NMR spectroscopy of natural organic matter. Prog Nucl Magn Reson Spectrosc 100:17-51. https://doi.org/10. 1016/j.pnmrs.2016.11.003

32. Nguyen PT (2014) Study of the aquatic dissolved organic matter from the Seine River catchment (France) by optical spectroscopy combined to asymmetrical flow field-flow fractionation. Analytical chemistry. Université de Bordeaux

33. Helms JR, Stubbins A, Ritchie JD, Minor EC, Kieber DJ, Mopper K (2008) Absorption spectral slopes and slope ratios as indicators of molecular weight, source, and photobleaching of Chromophoric dissolved organic matter. Limnol Oceanogr 53(3):955 
34. Hansen AM, Kraus TEC, Pellerin BA, Fleck JA, Downing BD, Bergamaschi BA (2016) Optical properties of dissolved organic matter (DOM): effects of biological and photolytic degradation. Limnol Oceanogr 61(2016):1015-1032. https://doi.org/10.1002//no.10270

35. Zsolnay A, Baigar E, Jimenez M, Steinweg B, Saccomandi F (1999) Differentiating with fluorescence spectroscopy the sources of dissolved organic matter in soils subjected to drying. Chemosphere 38:45-50

36. Huguet A, Vacher L, Relexans S, Saubusse S, Froidefond JM, Parlanti E (2009) Properties of fluorescent dissolved organic matter in the Gironde estuary. Org Geochem 40:706-719

37. Parlanti E, Wörz K, Geoffroy L, Lamotte M (2000) Dissolved organic matter fluorescence spectroscopy as a tool to estimate biological activity in a coastal zone submitted to anthropogenic inputs. Org Geochem 31(12):1765-1781. https://doi.org/10.1016/S0146-6380 (00)00124-8

38. Matar Z (2012) Influence de la matière organique dissoute d'origine urbaine sur la spéciation et la biodisponibilité des métaux dans les milieux récepteurs anthropisés, Thèse Université Paris-Est, Champs-sur-Marne, $258 \mathrm{p}$

39. Pernet-coudrier B, Clouzot L, Varrault G, Tusseau-vuillemin MH, Verger A, Mouchel JM (2008) Dissolved organic matter from treated effluent of a major wastewater treatment plant: characterization and influence on copper toxicity. Chemosphere 73:593-599

40. Town RM, Filella M (2000) A comprehensive systematic compilation of complexation parameters reported for trace metals in natural waters. Aquat Sci 62:252-295

41. Thurman EM, Malcolm RL (1981) Preparative isolation of aquatic humic substances. Environ Sci Technol 15:463-466

42. Martin-Mousset B, Croue JP, Lefebvre E, Legube B (1997) Distribution and characterization of dissolved organic matter of surface waters. Water Res 31:541-553

43. Perdue EM, Ritchie JD (2003) Dissolved organic matter in freshwaters. Treatise on Geochem 5:273-318

44. McDonald S, Bishop AG, Prenzler PD, Robards K (2004) Analytical chemistry of freshwater humic substances. Anal Chim Acta 527:105-124

45. Leenheer JA et al (2000) Comprehensive isolation of natural organic matter from water for spectral characterizations and reactivity testing. American Chemical Society, Washington, pp 68-83

46. Croue JP (2004) Isolation of humic and non-humic NOM fractions: structural characterization. Environ Monit Assess 92:193-207

47. Pernet-Coudrier B, Companys E, Galceran J, Morey M, Mouchel JM, Puy J, Ruiz N, Varrault G (2011) Pb-binding to various dissolved organic matter in urban aquatic systems: key role of the most hydrophilic fraction. Geochim Cosmochim Acta 75:4005-4019

48. Muresan B, Pernet-Coudrier B, Cossa D, Varrault G (2011) Measurement and modeling of mercury complexation by dissolved organic matter isolates from freshwater and effluents of a major wastewater treatment plant. Appl Geochem 26:2057-2063

49. Louis Y, Pernet-Coudrier B, Varrault G (2014) Implications of effluent organic matter and its hydrophilic fraction on zinc(II) complexation in rivers under strong urban pressure: aromaticity as an inaccurate indicator of DOM-metal binding. Sci Total Environ 490:830-837. https://doi. org/10.1016/j.scitotenv.2014.04.1230048-9697/

50. Moon J-W, Goltz MN, Ahn K-H, Park J-W (2003) Dissolved organic matter effects on the performance of a barrier to polycyclic aromatic hydrocarbon transport by groundwater. J Contam Hydrol 60:307-326

51. Newcombe G, Morrison J, Hepplewhite C (2002a) Simultaneous adsorption of MIB and NOM onto activated carbon. I. Characterisation of the system and NOM adsorption. Carbon 40:2135-2146

52. Newcombe G, Morrison J, Hepplewhite C, Knappe DRU (2002b) Simultaneous adsorption of MIB and NOM onto activated carbon: II. Competitive effects. Carbon 40:2147-2156

53. Li Q, Snoeyink VL, Mariñas BJ, Campos C (2003) Pore blockage effect of NOM on atrazine adsorption kinetics of PAC: the roles of PAC pore size distribution and NOM molecular weight. Water Res 37:4863-4872 
54. Saada A, Breeze D, Crouzet C, Cornu S, Baranger P (2003) Adsorption of arsenic (V) on kaolinite and on kaolinite-humic acid complexes: role of humic acid nitrogen groups. Chemosphere 51:757-763

55. Wu P, Tang Y, Wang W, Zhu N, Li P, Wu J, Dang Z, Wang X (2011a) Effect of dissolved organic matter from Guangzhou landfill leachate on sorption of phenanthrene by Montmorillonite. J Colloid Interface Sci 361:618-627

56. Wu P, Zhang Q, Dai Y, Zhu N, Dang Z, Li P, Wu J, Wang X (2011b) Adsorption of Cu (II), $\mathrm{Cd}$ (II) and $\mathrm{Cr}$ (III) ions from aqueous solutions on humic acid modified Camontmorillonite. Geoderma 164:215-219

57. Soares Pereira-Derome C (2016) Influence de la matière organique dissoute d'origine urbaine sur la spéciation des micropolluants: de la station d'épuration au milieu récepteur. Thèse, Université Paris-Est, Champs-sur-Marne, $297 \mathrm{p}$

58. Chaminda GGT, Nakajima F, Furumai H (2008) Heavy metal ( $\mathrm{Zn}$ and $\mathrm{Cu}$ ) complexation and molecular size distribution in wastewater treatment plant effluent. Water Sci Technol 58:1207-1213

59. Benedetti MF, Van Riemsdijk WH, Koopal LK, Kinniburgh DG, Gooddy DC, Milne CJ (1996) Metal ion binding by natural organic matter: from the model to the field. Geochim Cosmochim Acta 60(14):2503-2513

60. Milne CJ, Kinniburgh DG, Tipping E (2001) Generic NICA-Donnan model parameters for proton binding by humic substances. Environ Sci Technol 35:2049-2059

61. Croue JP, Benedetti MF, Violleau D, Leenheer JA (2003) Characterization and copper binding of humic and nonhumic organic matter isolated from the South Platte River: evidence for the presence of nitrogenous binding site. Environ Sci Technol 37(2):328-336

62. Knepper T (2003) Synthetic chelating agents and compounds exhibiting complexing properties in the aquatic environment. Trac-Trends Anal Chem 22:708-724

63. Markich SJ, Brown PL, Jeffree RA, Lim RP (2003) The effects of pH and dissolved organic carbon on the toxicity of cadmium and copper to a freshwater bivalve: further support for the extended free ion activity model. Arch Environ Contam Toxicol 45:479-491

64. Schwartz ML, Curtis PJ, Playle RC (2004) Influence of natural organic matter source on acute copper, lead, and cadmium toxicity to rainbow trout (Oncorhynchus mykiss). Environ Toxicol Chem 23:2889-2899

65. De Schamphelaere KAC, Vasconcelos FM, Tack FMG, Allen HE, Janssen CR (2004) Effect of dissolved organic matter source on acute copper toxicity to Daphnia magna. Environ Toxicol Chem 23:1248-1255

66. DePalma S-G-S, Arnold W-R, McGeer JC, Dixon DG, Smith DS (2011) Effects of dissolved organic matter and reduced sulphur on copper bioavailability in coastal marine environments. Ecotoxicol Environ Saf 74:230-237

67. Trenfield MA, McDonald S, Kovacs K, Lesher EK, Pringle JM, Markich SJ, Ng JC, Noller B, Brown PL, van Dam RA (2011) Dissolved organic carbon reduces uranium bioavailability and toxicity. 1. Characterization of an aquatic fulvic acid and its complexation with uranium VI. Environ Sci Technol 45:3075-3081

Open Access This chapter is licensed under the terms of the Creative Commons Attribution 4.0 International License (http://creativecommons.org/licenses/by/4.0/), which permits use, sharing, adaptation, distribution and reproduction in any medium or format, as long as you give appropriate credit to the original author(s) and the source, provide a link to the Creative Commons licence and indicate if changes were made.

The images or other third party material in this chapter are included in the chapter's Creative Commons licence, unless indicated otherwise in a credit line to the material. If material is not included in the chapter's Creative Commons licence and your intended use is not permitted by statutory regulation or exceeds the permitted use, you will need to obtain permission directly from the copyright holder.

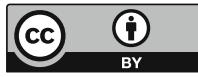

